Lingua Rima: Jurnal Pendidikan Bahasa dan Sastra Indonesia

Vol. 10 No. 2 Juli 2021

http://jurnal.umt.ac.id/index.php/lgrm

\title{
ANALISIS KESALAHAN FRASA PADA TEKS BERITA COVID-19 KORAN DIGITAL GORIAU.COM
}

\author{
Intan Kumala Dyah Hapsari ${ }^{1}$ \\ Universitas Ahmad Dahlan \\ intan1800003156@webmail.uad.ac.id \\ Riska Warni Harahap ${ }^{2}$ \\ Universitas Ahmad Dahlan \\ riska1800003155@webmail.uad.ac.id \\ Alviansyah Bonde ${ }^{3}$ \\ Universitas Ahmad Dahlan \\ alviansyah1800003153@webmail.uad.ac.id \\ Ibnu Adnan Cahya ${ }^{4}$ \\ Universitas Ahmad Dahlan \\ ibnu1800003152@webmail.uad.ac.id
}

\begin{abstract}
ABSTRAK
Surat kabar atau koran digital merupakan media informasi dalam format elektronik yang dapat dibaca dan diakses melalui komputer atau gawai oleh masyarakat. Dalam surat kabar, kesalahan penggunaan bahasa Indonesia masih banyak ditemukan, terutama kesalahan pada tataran sintaksis bidang frasa. Penelitian ini bertujuan untuk mendeskripsikan kesalahan bidang frasa pada teks berita Covid-19 di koran digital GoRiau.com edisi Mei. Penelitian ini menggunakan jenis penelitian kualitatif dengan menggunakan metode deskriptif. Subjek penelitian ini adalah berita Covid-19 di koran digital GoRiau.com edisi Mei, sedangkan objek penelitian ini adalah kesalahan bidang frasa. Metode pengumpulan data dilakukan dengan menggunakan teknik simak dan catat. Metode analisis data menggunakan metode padan ekstralingual. Instrumen penelitian yang digunakan berupa teks berita Covid-19 di koran digital GoRiau.com edisi Mei. Hasil penelitian ini sebagai berikut. (1) adanya pengaruh bahasa daerah, (2) penggunaan preposisi yang tidak tepat, (3) penggunaan unsur yang berlebihan, (4) penggunaan bentuk superlatif yang berlebihan, dan (5) penjamakan ganda.
\end{abstract}

Kata Kunci: sintaksis, kesalahan bidang frasa, GoRiau.com.

\section{A. PENDAHULUAN}

Kapasitas bahasa Indonesia sebagai sarana komunikasi dapat dimanfaatkan dalam berbagai kegiatan untuk menyampaikan informasi atau tujuan tertentu, baik dalam bentuk lisan maupun tertulis. Informasi yang disampaikan dalam bentuk lisan dapat dipeoleh melalui radio, dan televisi. Sedangkan informasi dalam bentuk tertulis dapat diperoleh melalui media massa, media massa digital, media cetak, dan lain-lain. Salah satu kelebihan dari media massa digital, khususnya pada kebutuhan akan informasi yang dapat diakses dari mana saja dengan perangkat sederhana saat ini, yaitu gawai. Efektif dan efisien dengan bermodal gawai dan 


\section{Lingua Rima: Jurnal Pendidikan Bahasa dan Sastra Indonesia \\ Vol. 10 No. 2 Juli 2021 \\ http://jurnal.umt.ac.id/index.php/lgrm}

koneksi internet, sudah dapat memenuhi setiap kebutuhan sehari-hari tiap individu. Perkembangan ilmu pengetahuan dan teknologi merambah pada kehadiran buku digital atau dikenal sebagai e-book. Begitu juga dengan penyajian berita, baik dalam bentuk tayangan ulang di Youtube atau koran digital. Di era modern 4.0, penyajian informasi atau berita juga dipermudah melalui situs koran digital.

GoRiau.com merupakan pemberitaan digital yang dibangun oleh Riau dalam rangka ikut andil mengembangkan media pemberitaan berbasis online yang memiliki banyak keunggulan dibandingkan media cetak lainnya. Kemampuan menjangkau jarak jauh bahkan ke pelosok daerah merupakan salah satu alasan Riau Bersama GoRiau.com membangun pemberitaan melalui koran digital. Kehadiran GoRiau.com merupakan sebuah kebanggaan dan menjadikan Riau mampu bersaing dengan berbagai daerah lainnya, bahkan berita yang terjadi di Riau dalam hitungan menit saja sudah bisa diketahui oleh masyarakat dari daerah lain termasuk pemerintah pusat. Akan tetapi, situs berita digital daerah maupun nasional yang beredar, khusunya situs berita digital GoRiau.com masih ditemukan kesalahan dalam penulisan yang mengakibatkan ketidakefektifan makna.

Persoalan bahasa sangat penting dalam bidang jurnalistik yaitu media massa karena bahasa merupakan media penyalur informasi. Sebuah informasi tidak akan tepat sasaran pada pembaca apabila bahasa ang digunakan tidak tepat (Alber, 2018:56). Oleh karena itu, perlu disadari oleh para pelaku bidang jurnalistik untuk menggunakan bahasa yang tepat. Penggunaan bahasa yang teapt yaitu bahasa Indonesia yang sesuai dengan kaidah bahasa dan tata baku bahasa yang mengaju pada Pedoman Umum Ejaan Bahasa Indonesia PUEBI. Ramlan (2010:18) mengungkapkan bahwa tata bahasa adalah bagian ilmu bahasa yang berbicara tentang kompleksitas wacana, kalimat, klausa, dan frasa, berbeda dengan morfologi yang mengkaji kompleksitas kata dan morfem. Struktur kalimat dikatakan teratur dan baik jika kalimat tersebut mengandung komponen subjek, predikat, objek, pelengkap, dan keterangan. Kalimat yang tidak menggunakan salah satu dari kelima komponen tersebut dianggap sebagai dalam tataran sintaksis. Kesalahan berbahasa tataran sintaksis dikelompokkan menjadi dua yaitu: kesalahan pada bidang frasa dan kesalahan pada bidang kalimat.

Kesalahan berbahasa dalam bidang frasa merupakan sebuah kesalahan yang terjadi dalam kaitannya dengan penggabungan kata yang bersifat nonpredikatif dan ketidaktepatan dalam penggunaannya. Kesalahan dalam bidang frasa dipengaruhi oleh beberapa hal misalnya 


\section{Lingua Rima: Jurnal Pendidikan Bahasa dan Sastra Indonesia \\ Vol. 10 No. 2 Juli 2021 \\ http://jurnal.umt.ac.id/index.php//grm}

pengaruh bahasa pertama, pengaruh bahasa daerah, penggunaan preposisi yang kurang tepat, kesalahan susunan kata, penggunakan kata yang mubazir, prnggunaan superlative yang berlebihan, penjamakan ganda, dan penggunaan resprokal yang kurang tepat (Setyawati dalam Alber, 2018:56). Oleh karena itu, peneliti dalam kesempatan ini memfokuskan masalah penelitian pada aspek kesalahan berbahasa tataran sintaksis bidang frasa. Kesalahan frasa sering dilakukan dalam bahasa lisan maupun tulis, akan tetapi dianggap benar karena sudah menjadi kebiasaan (Berutu dan Sanggup, 2017: 173). Kesalahan berbahasa bidang frasa meliputi adanya pengaruh bahasa daerah, penggunaan preposisi yang tidak tepat, susunan kata tidak tepat, penggunaan unsur yang berlebihan, penggunaan bentuk superlatif yang berlebihan, penjamakan ganda, dan penggunaan bentuk resiprokal yang salah (Setyawati, 2010:68).

Hasil penelitian sebelumnya dilakukan oleh Novita S. B, Berutu (2017) dengan judul Analisis Kesalahan Struktur Frasa dalam Teks Eksposisi Siswa Kelas X SMA Negeri 15 Medan Tahun Pembelajaran 2016/2017. Hasil penelitian tersebut ditemukan kesalahan dalam frasa yaitu frasa benda, frasa kerja, frasa sifat, frasa depan dan frasa keterangan. Sedangkan penelitian yang dilakukan oleh Alber (2018) dengan judul Analisis Kesalahan Penggunaan Frasa pada Tajuk Rencana Surat Kabar Kompas menghasilkan penggunaan preposisi yang tidak tepat, dan penggunaan unsur yang berlebihan. Berdasarkan penelitian sebelumnya, peneliti tertarik untuk meneliti mengenai kesalahan berbahasa pada frasa. Oleh karena itu, tujuan penelitian ini untuk mengetahui kesalahan berbahasa tataran sintaksis bidang frasa pada teks berita covid-19 di koran digital GoRiau.com edisi Mei.

\section{B. METODOLOGI PENELITIAN}

Jenis penelitian yang digunakan yakni kualitatif deskriptif. Penelitian kualitatif berangkat dari isu-isu yang dibawa oleh para peneliti yang masih samar, dan dinamis. Sumber data penelitian ini yaitu teks berita covid-19 di koran digital GoRiau.com edisi Mei. Data dalam penelitian ini yaitu kesalahan berbahasa tataran sintaksis bidang frasa. Penelitian ini menggunakan metode simak dan catat untuk metode pengumpulan data. Metode analisis data menggunakan metode padan ekstralingual. Metode ini digunakan untuk menganalisis unsur yang bersifat ekstralingual, misalnya menghubungkan persoalan bahasa dengan hal-hal di luar bahasa

\section{HASIL PENELITIAN DAN PEMBAHASAN}




\section{Lingua Rima: Jurnal Pendidikan Bahasa dan Sastra Indonesia \\ Vol. 10 No. 2 Juli 2021 \\ http://jurnal.umt.ac.id/index.php/lgrm}

Hasil penelitian pada analisis kesalahan berbahasa bidang frasa pada teks berita covid19 di koran digital GoRiau.com edisi Mei 2021 ditemukan lima kesalahan berbahasa di antaranya; (1) adanya pengaruh bahasa daerah, (2) penggunaan preposisi yang tidak tepat, (3) penggunaan unsur yang berlebihan, (4) penggunaan bentuk superlatif yang berlebihan, dan (5) penjamakan ganda. Hasil penelitian kesalahan berbahasa dalam bidang frasa yang terdapat dalam teks berita covid-19 di koran digital GoRiau.com menunjukan hal-hal sebagai berikut.

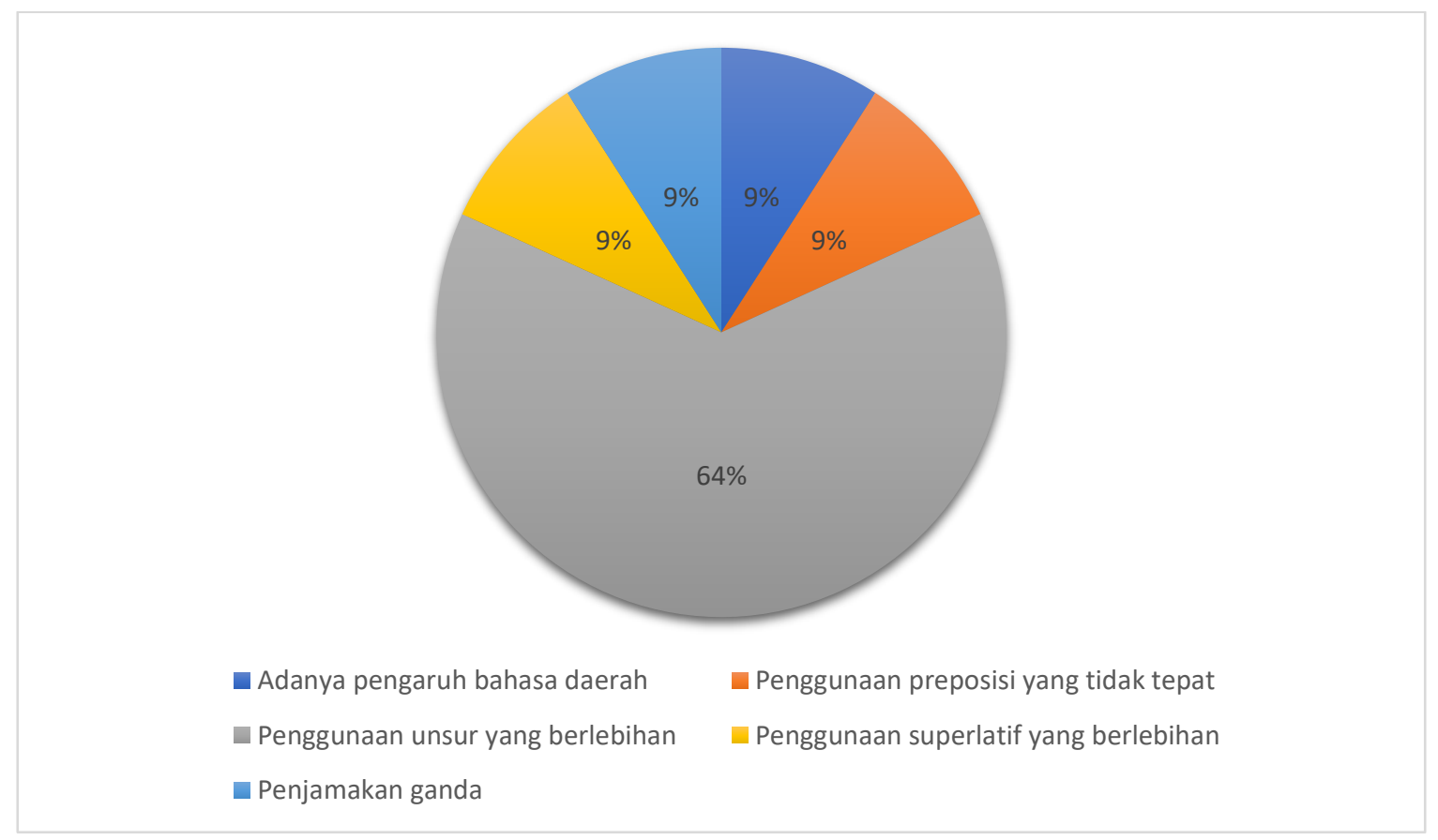

Diagram 4.1 Hasil Analisis Kesalahan Berbahasa Bidang Frasa

Data yang diperoleh dari hasil penelitian diatas kemudian akan dibahas pada bagian ini. Berdasarkan data yang diperoleh, terdapat empat jenis kesalahan berbahasa bidang frasa yang ditemukan dalam teks berita covid-19 di koran digital GoRiau.com edisi Mei 2021. Jenis kesalahan tersebut berupa adanya pengaruh bahasa daerah, penggunaan preposisi yang tidak tepat, penggunaan unsur yang berlebihan, penggunaan bentuk superlatif yang berlebihan, dan penjamakan ganda. Berikut pembahasan data yang telah diperoleh.

\section{Adanya Pengaruh Bahasa Daerah}

Situasi kedwibahasaan yang ada di Indonesia memberikan pengaruh yang signifikan dalam pemakaian bahasa. Adanya kecenderungan bahasa daerah (B1), sedangkan bahasa Indonesia merupakan (B2) bagi pemakai bahasa. Sehingga tidak mengherankan apabila terjadi kesalahan berbahasa karena adanya pengaruh bahasa daerah (B1) yang masih sering 


\section{Lingua Rima: Jurnal Pendidikan Bahasa dan Sastra Indonesia \\ Vol. 10 No. 2 Juli 2021 \\ http://jurnal.umt.ac.id/index.php/lgrm}

digunakan oleh masyarajat Indonesia. Data yang telah diperoleh berdasarkan kategori adanya pengaruh bahasa daerah berjumlah 1 data. Data tersebut sebagai berikut.

(1) Juru bicara vaksinasi covid-19 Kemenkes RI, dr. Siti Nadia Tarmidzi mengungkapkan, vaksinasi ditargetkan rampung pada Desember tahun ini.

Kalimat (1) merupakan bentuk kesalahan berbahasa adanya pengaruh bahasa daerah. Kata rampung dalam kalimat tersebut merupakan pemakaian yang salah disebabkan adanya pengaruh bahasa daerah. Kesalahan pada kata rampung sebaiknya diganti dengan kata selesai, sehingga perbaikan kesalahan tersebut menjadi 'Juru bicara vaksinasi covid-19 Kemenkes RI, dr. Siti Nadia Tarmidzi mengungkapkan, vaksinasi ditargetkan selesai pada Desember tahun ini.'

\section{Penggunaan Preposisi yang Tidak Tepat}

Pemakaian preposisi yang tidak tepat sering dijumpai dalam setiap pemakaian bahasa. Hal ini biasa terjadi pada preposisi yang menyatakan tujuan, waktu, dan tempat. Berikut preposisi yang tidak tepat yang ditemukan dalam sumber data. Data yang telah diperoleh berdasarkan kategori penggunaan preposisi yang tidak tepat berjumlah 1 data. Data tersebut sebagai berikut.

(2) Kondisi ini dimungkinkan kepada ditiadakannya salat Idul Fitri (Ied) 1442 Hijriah secara berjamaah yang digelar di masjid ataupun lapangan terbuka.

Kalimat (2) merupakan bentuk kesalahan berbahasa pada penggunaan preposisi yang tidak tepat. Kesalahan penggunaan preposisi yang tidak tepat terletak pada kata kepada, karena konjungsi kepada digunakan untuk menunjukkan orang. Kesalahan pada kata kepada sebaiknya diganti dengan kata akan, sehingga perbaikan kesalahan tersebut menjadi 'Kondisi ini dimungkinkan akan ditiadakannya salat Idul Fitri (Ied) 1442 Hijriah secara berjamaah yang digelar di masjid ataupun lapangan terbuka.'

\section{Penggunaan Unsur yang Berlebihan}

Pemakaian kata-kata yang mengandung makna yang sama (sinonim) sering dijumpai digunakan sekaligus dalam sebuah kalimat. Penggunaan kata-kata yang memiliki makna sama merupakan bentuk penggunaan unsur yang berlebihan. Berikut unsur yang berlebihan ditemukan dalam sumber data. Data yang telah diperoleh berdasarkan kategori penggunaan unsur yang berlebihan berjumlah 7 data. Data tersebut sebagai berikut.

(3) Seluruh tenaga kesehatan ASN yang tewas atau gugur dalam tugas diberikan santunan dan penghargaan sesuai aturan yang berlaku.

(4) Jadi artinya sudah terbentuk klaster baru, klaster perusahaan PT BMA, terang Asril. 


\section{Lingua Rima: Jurnal Pendidikan Bahasa dan Sastra Indonesia \\ Vol. 10 No. 2 Juli 2021 \\ http://jurnal.umt.ac.id/index.php//grm}

(5) Kapolres Inhil menyebutkan, mengatakan jumlah lansia yang melaksanakan vaksinasi sebanyak 429 orang.

(6) Selain itu untuk menurunkan tingkat yang terpapar atau terinfeksi Covid-19 dan mendorong terbentuknya imun tubuh (Herd Immunity) karena hal tersebut dapat mengurangi tingkat penularan.

(7) Kasus positif Covid-19 di Dumai masih terus mengalami peningkatan jumlah pasien positif pascalebaran.

(8) Walaupun masih dalam suasana lebaran, saat ini kondisi di daerah tersebut lengang, tidak ada aktifitas apapun dari warga.

(9) Dengan adanya penambahan ini, maka secara keseluruhan total kasus terkonfirmasi Covid-19 di Riau menjadi 58.856 kasus.

Unsur-unsur yang dicetak miring pada kalimat (3) sampai dengan (9) merupakan kesalahan yang disebabkan karena adanya penggunaan unsur yang berlebihan. Pada kalimat (3) lebih tepat menggunakan salah satu dari kata tewas dan gugur yang merupakan kata bersinonim atau memiliki makna yang sama. Pada kalimat (4) lebih tepat menggunakan salah satu dari kata jadi dan artinya yang merupakan kata untuk menyatakan penjelasan dari apa yang dibicarakan. Pada kalimat (5) lebih tepat menggunakan salah satu dari kata menyebutkan dan mengatakan yang merupakan kata untuk menyatakan dan bersinonim. Pada kalimat (6) lebih tepat menggunakan salah satu dari kata terpapar dan terinfeksi yang merupakan kata bersinonim atau memiliki makna yang sama. Pada kalimat (7) lebih tepat menggunakan salah satu dari kata masih dan terus yang merupakan kata untuk menyatakan berlangsung terusmenerus. Pada kalimat (8) lebih tepat menggunakan salah satu dari kata lengang dan tidak ada aktifitas yang merupakan kata bersinonim atau memiliki makna yang sama. Pada kalimat (9) lebih tepat menggunakan salah satu dari kata keseluruhan dan total yang merupakan kata bersinonim atau memiliki makna yang sama. Kalimat yang sudah diperbaiki menjadi seperti berikut.

(3) Seluruh tenaga kesehatan ASN yang gugur dalam tugas diberikan santunan dan penghargaan sesuai aturan yang berlaku.

(4) Jadi sudah terbentuk klaster baru, klaster perusahaan PT BMA, terang Asril.

(5) Kapolres Inhil mengatakan jumlah lansia yang melaksanakan vaksinasi sebanyak 429 orang.

(6) Selain itu untuk menurunkan tingkat yang terinfeksi Covid-19 dan mendorong terbentuknya imun tubuh (Herd Immunity) karena hal tersebut dapat mengurangi tingkat penularan.

(7) Kasus positif Covid-19 di Dumai terus mengalami peningkatan jumlah pasien positif pascalebaran.

(8) Walaupun masih dalam suasana lebaran, saat ini kondisi di daerah tersebut tidak ada aktifitas apapun dari warga.

(9) Dengan adanya penambahan ini, maka secara keseluruhan kasus terkonfirmasi Covid19 di Riau menjadi 58.856 kasus.

4. Penggunaan Bentuk Superlatif yang Berlebihan 


\section{Lingua Rima: Jurnal Pendidikan Bahasa dan Sastra Indonesia \\ Vol. 10 No. 2 Juli 2021 \\ http://jurnal.umt.ac.id/index.php/lgrm}

Bentuk superlatif adalah suatu bentuk yang mengandung arti 'paling' dalam suatu korelasi. Bentuk yang mengandung arti 'paling' dapat dihasilkan dengan suatu adjektiva ditambah adverbial amat, sangat, sekali, atau paling. Jika dua adverbia digunakan secara bersamaan untuk memperjelas adjektiva pada sebuah kalimat, terjadilah bentuk superlatif yang berlebihan. Berikut bentuk superlatif yang berlebihan ditemukan dalam sumber data. Data yang telah diperoleh berdasarkan kategori bentuk superlatif yang berlebihan berjumlah 1 data. Data tersebut sebagai berikut.

(10) Namun untuk di Kecamatan lain seperti Sungai Mandau, Pusako yang jumlah penduduknya minoritas, kasus ini bisa dibilang sangat kecil sekali angkanya, berkisar 1 sampai 2 saja, kata Budi Yuwono usai mengikuti Rakor terkait penanganan Covid-19 dengan Gubri secara virtual.

Kalimat (10) merupakan bentuk kesalahan berbahasa penggunaan bentuk superlatif yang berlebihan. Kata sekali dalam kalimat tersebut merupakan bentuk penggunaan superlatif yang berlebihan. Kata sekali tidak perlu digunakan secara bersamaan dengan kata sangat. Kata sekali dapat dihilangkan sehingga susunan frasanya menjadi sangat kecil angkanya. Maka bentuk baku kalimat tersebut "namun untuk di Kecamatan lain seperti Sungai Mandau, Pusako yang jumlah penduduknya minoritas, kasus ini bisa dibilang sangat kecil angkanya, berkisar 1 sampai 2 saja, kata Budi Yuwono usai mengikuti Rakor terkait penanganan Covid19 dengan Gubri secara virtual'.

5. Penjamakan Ganda

Seringkali orang salah menggunakan bentuk jamak dalam bahasa Indonesia, sehingga terjadi kerancuan yang diakibatkan oleh penggunaan bentuk jamak yang dilakukan secara berulang. Berikut penjamakan ganda yang ditemukan dalam sumber data. Data yang telah diperoleh berdasarkan kategori penjamakan ganda berjumlah 1 data. Data tersebut sebagai berikut.

(11) Saya masih melihat kondisi-kondisi kerumunan-kerumunan yang memang tidak diperlukan di Pekanbaru, nongkrong malam-malam.

Kalimat (11) merupakan bentuk kesalahan berbahasa yang mengandung penjamakan ganda. Pada penulisan kalimat kondisi-kondisi dan kerumunan-kerumunan akan lebih efektif apabila diganti menjadi kondisi kerumunan agar tidak mengakibatkan kerancuan dalam memahami makna kalimat, sehingga perbaikan kesalahan tersebut menjadi 'saya masih melihat kondisi kerumunan yang memang tidak diperlukan di Pekanbaru, nongkrong malammalam'.

\section{SIMPULAN DAN SARAN}


Lingua Rima: Jurnal Pendidikan Bahasa dan Sastra Indonesia

Vol. 10 No. 2 Juli 2021

http://jurnal.umt.ac.id/index.php//grm

Berdasarkan hasil dan pembahasan di atas, masih banyak dijumpai kesalahan berbahasa dalam surat kabar digital, khususnya pada teks berita Covid-19 di koran digital GoRiau.com edisi Mei 2021. Kesalahan bidang frasa yang muncul berupa adanya pengaruh bahasa daerah sebanyak 1 data, penggunaan preposisi yang tidak tepat sebanyak 1 data, penggunaan unsur yang berlebihan sebanyak 7 data, penggunaan bentuk superlatif yang berlebihan sebanyak 1 data, dan penjamakan ganda sebanyak 1 data. Berdasarkan hasil penelitian yang dilakukan, terdapat beberapa saran yang berkaitan dengan penelitian ini yaitu (1) penelitian mengenai kesalahan berbahasa pada tataran sintaksis bidang frasa harus terus dilakukan untuk mengetahui aspek-aspek kesalahan berbahasa. Oleh karena bahasa terus berkembang, kesalahan dalam berbahasa juga turut berkembang seiring dengan penutur bahasa itu sendiri, (2) bagi peneliti selanjutnya, disarankan untuk meneliti aspek kesalahan berbahasa lainnya, seperti kesalahan berbahasa tataran sintaksis bidang kalimat.

\section{E. DAFTAR PUSTAKA}

Alber. 2018. Analisis Kesalahan Penggunaan Frasa pada Tajuk Rencana Surat Kabar Kompas. Madah. Vol 9 No 1 PP 55-62

Berutu, Novitas S. B. dan Barus, Sanggup. 2017. Analisis Kesalahan Struktur Frasa dalam Teks Eksposisi Siswa Kelas X SMA Negeri 15 Medan Tahun Pembelajaran 2016/2017. Vol 6 No 3 PP 169-176

Ramlan, M. (2010). Sintaksis. Surakarta: Yuma Pustaka.

Setyawati, N. (2010). Analisis Kesalahan Berbahasa Indonesia. Surakarta: Yuma Pustaka. 